\title{
Metafora jako prubířský kámen teorií významu
}

\author{
Metaphor as a touchstone of theories of meaning
}

\author{
Josef Zeman
}

Fakulta Filozofická

Západočeská univerzita v Plzni

Sedláčkova 38, 30614 Plzeň

zemanj@students.zcu.cz

\begin{abstract}
Abstrakt/Abstract
Cílem této studie je prozkoumat postavení metafory na poli zkoumání významu a následně představit potenciál metafory, a obrazných vyjádření obecně, zastávat pozici kritéria hodnocení teorií významu. Jako výchozí bod si práce bere několik vlivných pojetí metafory, na nichž ukazuje šíri bádání o metafoře a obraznosti a zároveň různorodost možných př́stupů $\mathrm{k}$ vysvětlení těchto jazykových fenoménů. Dále je věnována pozornost několika sporným bodům opakovaně se objevujícím v různých teoriích metafory. $\mathrm{Na}$ základě analýzy těchto sporných bodů jsou předloženy argumenty zpochybňující předpokládanou odlišnost mechanismů konstituování významu u obrazných a doslovných vyjádření. Následkem toho je pak vznesen návrh, zda by metafora, pro své kvalitativní a kvantitativní rysy, nemohla být chápána jako prubîrský kámen teorií významu, tj. byla nástrojem $\mathrm{k}$ hodnocení těchto teorií, $\mathrm{k}$ jejich falsifikování, modifikování či přímo $\mathrm{k}$ jejich vytváření.
\end{abstract}

The main aim of this study is to examine the role that metaphor plays in investigation of linguistic meaning and to present the potential of metaphor and figurative language in general to maintain a position of an evaluating criterion for theories of meaning. Several influential theories of metaphor are used as a starting point for this inquiry, to show how vast the field of investigation of metaphors and figurative language might be and how various approaches attempt to explain these language phenomena. I then focus on a number of problematic points repeatedly resurfacing in various theories of metaphor. My analysis of these problems issues in arguments questioning supposed difference between constituting mechanisms of literal and figurative meaning. Having this in place, I propose that, on account of its quantitative and qualitative features, metaphor could be understood as a touchstone of theories of meaning, i.e. the tool for their evaluating, refuting, modifying and even for creating new ones.

Přestože metafoře a obrazným vyjádřením je ve filosofii jazyka věnováno čím dál tím více pozornosti, stále spíše dominuje přesvědčení, že obraznost je specifickou či nějak

${ }^{1}$ Tento článek vznikl v rámci řešení projektu ZČU SGS-2016-017. 
deviantní formou vyjádření principiálně odlišnou od doslovnosti, a tudíž problematikou pro zkoumání významu vedlejší a nepř́iliš podstatnou. Toto přesvědčení pak většinou ústí ve striktní oddělování zkoumání významu, které je primárně zkoumáním významu doslovného, a zkoumání metafory, a to aniž by byl nějak uspokojivě vyjasněn vztah mezi nimi. Protože je metafora nakonec většinou trivializována za účelem kompatibility s teoriemi významu, je metafoře přisouzena pozice zajímavého, nicméně marginálního jevu.

Moderní teorie metafory však tím, že poměrně úspěšně popírají klasickou představu významu jako jakési abstraktní entity přenášené z doslovných vyjádření na zástupná obrazná vyjádření, znovu otevírají otázku po tom, jaký je vztah mezi metaforou a doslovností. Nemohou být obrazná vyjádření, nejsou-li jen pouhým zástupcem doslovného vyjádření, nějakým způsobem přínosná na poli zkoumání významu? Cílem tohoto př́spěvku je tedy zamyslet se nad možným postavením metafory v otázce významu a zároveň se pokusit představit hypotézu, zda by metafora nemohla plnit roli hodnotícího kritéria teorií významu.

\section{Teorie metafory}

V otázce role metafory na poli významu nepanuje jednotný postoj. Je tomu tak jednoduše proto, že současné teorie metafory jsou mezi sebou $\mathrm{v}$ mnoha ohledech naprosto nesouměřitelné. Nevyhneme se tak krátkému exkurzu do teorií metafory, protože je nejdřive vhodné shrnout, jaké různé vztahy k otázce významu, resp. vztahy metafory $\mathrm{k}$ doslovným vyjádřením, jsou různými teoriemi metafoře připisovány.

Jazykový fenomén zvaný metafora je poprvé zkoumán již u klasických antických autorů. Nejčastěji se v souvislosti s metaforou uvádí Aristoteles, Quintilian a Cicero. ${ }^{2}$ Metafora jimi byla chápána jako dočasná změna běžného významu slova. Aristoteles za metaforu považuje každé užití obrazného významu na místo doslovného. Jedná se o přenesení jména jedné věci na věc druhou. ${ }^{3}$ Aristoteles dále rozlišuje několik typů tohoto přenosu. Quintilian a Cicero již považují za metaforu pouze jeden z těchto typů přenášení významu a to ten, který je založen na analogii či podobnosti ${ }^{4}$ a který Aristoteles nazýval přenesení jména dle obdoby. ${ }^{5}$

Metafora je $\mathrm{v}$ řeči užívána proto, že jí přidává na expresivnosti a tím ji činí zajímavější a líbivější. Metafory dodávají textu na uměleckosti a nevšednosti a potěší

\footnotetext{
${ }^{2}$ Hills (2012, kap. The Ancient Accounts).

${ }^{3}$ Aristotelés (1999, Poetika II, 21, 1457b10).

${ }^{4}$ Hills (2012, kap. The Ancient Accounts).

${ }^{5}$ Aristotelés (1999, Poetika II, 21, 1457b20).
} 
posluchače stimulací imaginace a rozptýlením mysli soustředěné na, svým způsobem, předvídatelný výklad. ${ }^{6}$ Metafory také baví posluchače tím, že před něj staví hádanku či úkol nalézt podobnost mezi obrazně užitým slovem a oním běžně užívaným slovem, které tento metaforický výraz zastupuje. Vyřešení této hádanky př́ijemci metafory ukazuje nové a nové spojitosti mezi věcmi. ${ }^{7}$ Tyto spojitosti mohou pak ukázat nepovšimnuté vlastnosti věcí být krásné, vznešené, ošklivé, vtipné či údiv vzbuzující. ${ }^{8}$ Metafory tak diváka nejen baví, ale též manipulují jeho pocity v souladu s autorovým záměrem. $^{9}$

V tomto nejstarším pojetí se poprvé setkáváme s rozlišením doslovnosti a obraznosti. Vztah mezi doslovným významem a metaforou zde lze označit jako zastoupení či přenos.

První z moderních pojetí metafory, tedy pojetí sémantického posunu, vychází z knihy The Philosophy of Rhetoric (1936) od I. A. Richardse a z článků Metaphor (1954) od M. Blacka a The Metaphorical Twist (1962) od M. Beardsleyho. Za metaforu je považovaná věta, která získala úplně nový metaforický význam tím, že obsahuje jedno či více slov, která v rámci věty získala nový obrazný význam. Toto nahrazení doslovného významu za metaforický se nazývá metaforický obrat ${ }^{10}$ či sémantický posun. Vztah mezi původním doslovným a novým metaforickým významem vychází bud' z podobnosti (I. A. Richards), či ze systému běžných asociací (M. Black). ${ }^{11} \mathrm{~K}$ vyvolání metaforického obratu je třeba napětí mezi metaforickým činitelem, tj. ohniskem, který je nějakým způsobem nesmyslný, deviantní a do věty nezapadající výraz, a nemetaforickým zbytkem věty, tj. rámcem. Součástí věty je, dle Blacka, nicméně i její kontext a situace promluvy. ${ }^{12}$ Obrazné vyjádření je tedy nějak transformovaným doslovným výrazem a to na základě napětí mezi částmi promluvy a kontextem. Pojetí sémantického posunu dále rozvíjel Harold Skulsky v článku Metaphorese (1986) svým pojetím metafory a ostatních tropů jako užití speciálního metaforického jazyka metaphorese. Ten je souborem metaforických významů vlastních určitému jazyku či kulturnímu prostředí, které posluchač aplikuje na promluvu mluvčího, nedává-li běžný

\footnotetext{
${ }^{6}$ Tamtéž (Poetika II, 22, 1458a30).

${ }^{7}$ Aristotelés (1999, Rétorika III, 10, 1410b25).

${ }^{8}$ Tamtéž (III, 2, 1405a).

${ }^{9}$ Pavelka (1982, s. 25).

${ }^{10}$ Termín „metaforický obrat“ razil M. Beardsley.

${ }^{11}$ Black (1954, s. 286).

${ }^{12}$ Black (1979, s. 24).
} 
doslovný význam slov v kontextu promluvy smysl. Skulsky chápe posun významu u metafor jako následek spolupráce či hry mezi mluvčím a posluchačem. ${ }^{13}$

V teoriích metafory jako sémantického posunu tedy pokračuje přesvědčení o rozdílu mezi obrazností a doslovností. Vztah mezi nimi je vysvětlen zhruba jako transformace, posun či náhrada doslovného významu ustanoveným významem metaforickým.

Pragmatické pojetí metafory bylo vytvořeno filosofem jazyka P. Gricem. Poprvé bylo formulováno v jeho přednášce Logic and Conversation (1989). Pojetí metafory vychází z důrazného odlišení toho, co je běžně chápáno jako význam věty, a toho, co je mluvčím větou sdělováno. ${ }^{14}$ Jinak řečeno - významem je zde chápáno to, co míní mluvčí, i když to může být v opozici k tomu, co znamenají jeho slova. Význam věty obecně, a tudíž i význam metafory se vyjevuje až při individuálním výkonu užití jazyka, tj. v rámci promluvy (utterance). Promluva je elementárním prvkem kooperativní činnosti zvané konverzace. $\mathrm{K}$ účasti na konverzaci je potřeba dodržovat pravidla a konsensy, které konverzaci konstituují. Osoby, které se účastní a podílejí na konverzaci, sledují jistý společný cíl. Ten může být jasný hned z počátku konverzace či se vyjevuje průběžně. Nicméně i $v$ druhém případě je určitý cíl od začátku alespoň předpokládán. Cíl konverzace je součástí samotné podstaty komunikace. Fakt, že konverzace je spolupráce na dosažení společného cíle, nazývá P. Grice princip kooperace. Dále, přijmeme-li konverzaci jako spolupráci směřující k dosažení určitého cíle, vyvstanou nám zároveň jistá pravidla, jejichž dodržování umožňuje dosažení tohoto cíle. Soubor těchto pravidel P. Grice nazývá konverzační maximy. Porušení principu kooperace znamená jednoduše konec konverzace. Případ porušení maxim konverzace je ale složitější a také zajímavější. Konverzace totiž stále pokračuje, udržovaná při životě stále trvajícím předpokladem dodržování principu kooperace, ale zároveň se v ní objevují zajímavé jazykové fenomény. Většinu z nich P. Grice sdružuje pod pojem konverzační implikatura. ${ }^{15}$ Ta se dá zjednodušeně popsat jako jazykový jev, kdy mluvčí míní něco jiného, než znamenají jeho slova. To, co je míněno, je nalezeno posluchačem tak, že upravuje význam řečeného až do bodu, kdy jsou maximy naplněny. Jedním typem konverzační implikatury je i metafora. V tomto pojetí se tak setkáváme se sdružením všech obrazných vyjádření tj. tropů pod jeden termín. Pojem metafora je sice pouze jeden $\mathrm{z}$ př́padů konverzační implikatury, ale teorie si dokáže poradit i s ironií, metonymií, hyperbolou apod.

\footnotetext{
${ }^{13}$ Hills (2012, kap. The Semantic Twist Accounts).

${ }^{14}$ Peregrin (2005, s. 178).

${ }^{15}$ Grice (1989, s. 26).
} 
V Griceově teorii dále pokračuje John Searle a propojuje ji se svým pojetím řečových aktů. Searle věnuje větší pozornost způsobům a metodám, kterými dochází posluchač na základě toho, co mluvčí řekl, k tomu, co mluvčí mínil. ${ }^{16}$ Searlův největší př́nos na poli zkoumání metafory je nicméně jeho snaha o vymezení toho, co je doslovný význam, vůči kterému metaforu definujeme a poznáváme. Doslovný význam v nulovém kontextu (který nacházíme např. ve výkladových slovnících) podle Searla neexistuje. ${ }^{17}$ Doslovný význam je relativní $\mathrm{k}$ jakýmsi našim předpokladi̊m $v$ pozadí (background assumptions), které tvoří rámec $\mathrm{k}$ uchopení doslovného významu. ${ }^{18}$ Toto pozadí je možno chápat jako jazykovou připravenost mluvčího a jeho obeznámenost se světem. Význam metafory je pak relevantní pouze ke kontextu promluvy. Dalo by se říci, že metafora je kreativní právě proto, že je vytvářena a chápána na základě nového, zatím neznámého rámce. Proces umírání metafory je pak jako ustalování tohoto rámce a jeho splývání a pronikání do stabilního rámce předpokladů v pozadí.

Dan Sperber a Deidre Wilson rozpracovávají Griceovské pojetí do teorie relevance. Všechny verbální produkty mluvčího, stejně jako nonverbální, jsou chápány jako evidence, na jejímž základě provádí posluchač inferenci o tom, co mluvčí mínil. Jako význam mluvčího je pak chápána nejrelevantnější inference, tedy taková, která přináší nejpřesnější a s kontextem nejvíce související informaci a která je zároveň pro mluvčího nejrychleji či nejsnadněji odvoditelná. Metafory jsou pak zajímavé pouze tím, že je tento základní jazykový princip na nich nejpatrnější. Kromě této „očividnosti“ se metafora ale nijak neliší od ostatních jazykových vyjádření. ${ }^{19}$

V pragmatickém pojetí, zvláště v jeho nejnovějších projevech, je tak patrné, že se pomalu ale jistě stírá rozdíl mezi obrazným a doslovným významem. Inferenční mechanismus je v teorii relevance stejný pro oba typy výrazů. Nicméně už i u Searla, přestože sám to odmítá, si lze povšimnout podobnosti mezi kontextuálním rámcem přidělujícím význam metaforám (a nepřímým řečovým aktům) a rámcem předpokladů v pozadí, vůči kterým je relativní doslovný význam. Druhé je spíše ustálenou a automatizovanou podobou prvního, než aby se jednalo o principiálně odlišný mechanismus.

Mimo uvedená pojetí, chápající obraznost jako transmutaci významu doslovného, existují i pojetí banalizující obraznost a metaforu jako pouhý případ nepovedené doslovné propozice. Už od dob Aristotela si totiž filosofové všímali zarážející podobnosti mezi metaforou a prrirovnáním. To vedlo k vytvoření pojetí metafory jako

\footnotetext{
${ }^{16}$ Mácha (2012, s. 188).

${ }^{17}$ Searle (1979b, s. 117).

${ }^{18}$ Tamtéž, s. 133.

${ }^{19}$ Sperber \& Wilson (2008, s. 87).
} 
eliptického prrirovnání. ${ }^{20}$ Výraznými proponenty tohoto pojetí byli už Cicero a Quintilianus, v současnosti např. R. Fogelin, kteří tvrdí, že metafora je pouze zkráceným či staženým přirovnáním. ${ }^{21}$ Toto tradiční komparativní pojetí má však několik úskalí. Zaprvé to, že doslovná přirovnání jsou symetrická. To znamená, že když A je podobné $B$, je i B podobné A. To však u metafory neplatí. Metaforu „Ten muž je lev“ nelze jednoduše přeměnit na „Ten lev je muž“, aniž by došlo k totální proměně významu této věty. ${ }^{22}$ Zadruhé, metafora je také jistým způsobem otevřená a má, dalo by se říci, hloubku. Podobnost mezi předměty není přímo uvedená a lze ji nalézt na více úrovních, čehož si je autor metafory samozřejmě vědom a používá tuto jazykovou figuru právě pro její mnohoznačnost. Přrirovnáním však autor ukáže pouze jeden specifický společný rys a přirovnání je tak ve srovnání s metaforou velmi povrchní a ploché. ${ }^{23}$ Zároveň je-li metafora jen zkráceným přirovnáním, pak by vlastně nikdy neměla být nejasná a nebylo by třeba ji nikterak luštit. Čtvrtou výraznou slabinou tradičního komparativního chápání metafory je to, že není schopné poradit si se složitějšími, např. vícevrstvými, metaforami jako je Searlův známý př́iklad „Sally je kus ledu. “24 Zde jsou Sally připisovány emoční vlastnosti, které led samozřejmě nemá a mít ani nemůže. Chápat v tomto př́padě větu jako prosté přirovnání není možné, protože i když doplníme větu na „Sally je jako kus ledu“, tak tím nic nevyřešíme a stále se budeme potýkat s metaforou. Sally sice sdílí vlastnost ledu (chlad), ale pouze vlastnost ledu chápanou metaforicky. ${ }^{25} \mathrm{Z}$ toho je patrné, že metafora je přirovnání nadřazená a nelze ji na něj redukovat. Odhlédneme-li na chvíli od nedostatků komparativistického pojetí, lze vztah mezi metaforou a doslovným vyjádřením v této teorii chápat zhruba jako identitu, protože metafora je vlastně pouze zkratkou pro doslovné vyjádření.

Kauzální pojetí metafory, které představil americký analytický filosof D. Davidson ve svém článku What Metaphors Mean (1978), postupuje v banalizaci obraznosti ještě dál. Ve svém pojetí metafory totiž rázně odmítá existenci jakýchkoli lingvistických mechanismů způsobujících změny významu slov v rámci metafory a navozujících tzv. metaforický význam. Metafora tak dle D. Davidsona není následkem nějakého sémantického posunu. $V$ metafoře nic nechybí a nemůže se tak jednat ani o zkrácené přirovnání. Metaforu nelze parafrázovat. Metafora prostě znamená pouze to, co znamenají doslovně chápaná slova v ní. ${ }^{26}$ Metaforou je pak efekt vycházející ze

\footnotetext{
${ }^{20}$ Lycan (2008, s. 179).

${ }^{21}$ Fogelin (1988, s. 26).

${ }^{22}$ Beardsley (1962, s. 297).

${ }^{23}$ Tamtéž, s. 294.

${ }^{24}$ Searle (1979a, s. 76).

${ }^{25}$ Lycan (2008, s. 180).

${ }^{26}$ Davidson (1978, s. 32).
} 
střetu těchto doslovných významů. Tento střet, toto spojení nesouvisejících slov (chápaných doslovně), postaví každé z nich do nového světla. Metafora nás doslova nutí nalézt nové, do té doby neuvědomělé podobnosti a vztahy mezi věcmi. ${ }^{27}$ Žádný z prvků metafory v té chvíli však nemění nijak svůj význam. Metafora jako celek nenese žádný kognitivní obsah, žádný význam. Je téměř vždy nepravdivá (na rozdíl od přirovnání, které je téměř vždy pravdivé). Vyvolává však jistý psychologický efekt - určitý typ mentálního obrazu podobného snovým obsahům. ${ }^{28}$ Otázka po konstituování významu obrazných vyjádření je tak vyřešena prohlášením, že žádný význam vlastně nemají.

V kauzálním přístupu k metafoře, nastaveném D. Davidsonem, pokračuje Richard Rorty (a užívá ho jako nástroj k polemizování o kulturních změnách, vývoji, morálce a politice v knize Nahodilost, ironie a solidarita (1986)). Metafora se od doslovných vyjádření liší svou novostí. Význam se odvíjí od pravdivostních podmínek a lze ho tedy připsat pouze vyjádřením (resp. akustickým produktům), se kterými jsme obeznámeni a pravdivostní podmínky tak mají. Obrazná vyjádření tak pro svou novost žádný význam vlastně nenesou. Metafory význam získávají až svým ustálením v řečových hrách, tj. v procesu umírání metafor. Mrtvá metafora, jejíž užití je již zafixované a obecně známé určitému společenství, získává pravdivostní podmínky a přestává tak být vyjádřením obrazným a stává se vyjádřením doslovným. ${ }^{29}$

Davidsonovo kauzální pojetí později obhajují i Ernie Lepore a Matt Stone ve svém článku Against metaforical meaning (2010). ${ }^{30}$ Vyrovnávají se zde s většinou námitek, které kontroverzní, mnohdy schematický a problematiku zjednodušující článek vyvolal. Metafora nemá, na rozdíl od doslovných vyjádření, význam. Metafora je pouze efektem, následkem, který je v nás vyvolán doslovným významem promluvy.

Metafora v kauzálním pojetí tak vlastně nemá žádný vztah k otázce významu a doslovným vyjádřením, protože sama žádný význam nenese a je pouhým psychologickým efektem. Je tak vlastně zpochybněna sama příslušnost metafory k jazyku.

V kauzálním pojetí metafory se sice metafoře upírá metaforický význam, nicméně přisuzují se jí zároveň vedle doslovného významu jejích částí nové vlastnosti, které mají být spíše psychologické než lingvistické povahy, např. síla, efekt, vliv. Je ale otázkou, zda doslovné výrazy nenesou podobné či dokonce stejné efekty, síly a vlivy, pouze v méně výrazné a patrné podobě. Metafora je sice způsobována kauzálně doslovným významem, ale i sám jazyk se svým doslovným významem je, dle Davidsona,

\footnotetext{
${ }^{27}$ Tamtéž, s. 33.

${ }^{28}$ Tamtéž, s. 46.

${ }^{29}$ Rorty (1989, s. 18).

${ }^{30}$ Lepore \& Stone (2010).
} 
způsobován kauzálně. ${ }^{31} \mathrm{Na}$ první pohled se zdá, že metafora je dalším článkem kauzálního řetězce svět -> jazyk a jeho významy ->metafora. Je tomu ale tak jen proto, že v případě jazyka obecně mluvíme o následku (jazyk je následkem světa) a u metafory mluvíme o prŕíčinách (jazyk je užit mluvčím $\mathrm{k}$ tomu, aby $\mathrm{v}$ posluchači zapříčinil povšimnutí si podobnosti - a toto povšimnutí je metaforou). Avšak předtím, než se mluvčí pokusí na takovou podobnost poukázat, musí si jí sám také nejdříve povšimnout. Metafora je tak v Davidsonově realismu dost možná nakonec stejným kauzálním následkem světa, jako je jazyk s jeho doslovnými významy.

Poslední z pojetí, která zde chci uvést, je pojetí metafory jako kognitivního konceptu. Tato filosofická pozice zatím nejsilněji rehabilituje postavení metafory ve filosofii jazyka a přiznává jí také zatím nejvýznamnější roli $\mathrm{v}$ rámci více jak dvoutisíciletého zkoumání fenoménu metafory. Nejznámějšími proponenty jsou G. Lakoff a M. Johnson se svým dílem Metafory, kterými žijeme (1980). Zde metafora není chápána jako pouhá figura jazyka, ale jako následek výkladu skutečnosti na základě myšlenkových konceptů abstrahovaných ze základní oblasti zkušenosti. ${ }^{32}$ Metafora je strukturace jedné zkušenosti na základě jiné. ${ }^{33}$ Strukturující koncepty a schémata (později, při užití $\mathrm{v}$ odlišné sféře skutečnosti než ve sféře původu, zvané metafory/metaforické koncepty) člověk získává jakousi podvědomou abstrakcí $\mathrm{Z}$ nejzákladnějších empirických dat týkajících se existence $\mathrm{v}$ prostoru a interakce $\mathrm{s}$ fyzickými objekty. Metafora tak už není primárně jazykovou figurou ale spíše jakýmsi transcendentálním mechanismem epistemologickým. Zdůrazňování uměleckosti a dekorativnosti metafory, které se v teoriích metafory objevuje jako následek tradičního antického chápání, je tak spíše jen svébytným užitím fenoménu metafory v rámci umění. $^{34}$

Lakoff své pojetí metafor dodnes rozvíjí a zpřesňuje v rámci kognitivních věd ve spojení s neurovědou. Dle Lakoffa se ukazuje, že i rozumění slovům a tomu, co bychom mohli označit za doslovné významy, funguje na stejném principu jako konceptuální metafory. ${ }^{35}$ Sít' doslovných významů a konceptuálních metafor se proplétají v rámci principu neurálního mapování.

\footnotetext{
${ }^{31}$ Peregrin (2005, s. 265).

${ }^{32}$ Lakoff \& Johnson (2002, s. 133).

33 Tamtéž, s. 94.

${ }^{34}$ Lakoff (1993, s. 246).

${ }^{35}$ Lakoff (2008, s. 36).
} 
S konceptuálním pojetím metafor je v úzkém vztahu i současný rozsáhlý zájem o výzkum analogie a její role v myšlení a otázce umělé inteligence. Konceptuální pojetí metafor se s tímto pojetím analogie značně překrývá. ${ }^{36}$

Metafora je tak $\mathrm{v}$ tomto pojetí fenomén natolik prostupující celý jazyk, že potenciálně může být velmi těžké nalézt nějaký doslovný význam neovlivněný metaforou. Toto pojetí sice neztotožňuje obrazný a doslovný význam, ale roli metafory v jazyce značně vyzdvihuje. Metafora je na poli významu téměř klíčovým hráčem, protože konceptuální metafory a analogie jsou jedním z hlavních principů lidského myšlení.

V tomto exkurzu se tedy setkáváme více méně se dvěma typy přístupů k hodnotě metafory při zkoumání významu. V klasickém, komparativistickém a kauzálním pojetí je role metafory při zkoumání významu spíše druhotná. Klasické pojetí považuje metaforu za primárně dekorativní prvek s významem půjčeným z doslovnosti, pro komparativisty je metafora pouze zkratkou za přirovnání a význam metafory je tak doslovným významem onoho přirovnání a $\mathrm{v}$ kauzálním pojetí nemá metafora $\mathrm{s}$ významem společného vůbec nic. Pojetí sémantického posunu je značně umírněnější, ale i zde je metafora spíše jen deviací od normy a posunem doslovného významu. Další dvě pojetí již tento, dle mého názoru, banalizující postoj nesdílejí. V obou případech se ustaluje jednota sémantických mechanismů doslovných a obrazných vyjádření. Při chápání metafory skrze pragmatické či konceptuální pojetí se tak poprvé ukazuje i potenciál metafory zastávat roli kritéria hodnocení teorií významu. Než bude ale možné přistoupit $\mathrm{k}$ rozvíjení této teze, je třeba se vyrovnat $\mathrm{s}$ důvody, které vedou $\mathrm{k}$ představě, že metafora je při zkoumání jazyka a významu fenoménem pouze druhotným. Za tyto důvody považuji problém extenze pojmu, fenomén podobnosti a hlavně předpoklad duality.

\section{Problém extenze pojmu}

Je patrné, že v každém z uvedených pojetí znamená pojem „,metafora“ něco naprosto jiného. Metafora je jednou přenos významu, jindy věta obsahující doslovný rámec a obrazné ohnisko, eliptické přrirovnání, snový obraz a psychologický účinek, kognitivní koncept či typ inference. Snaha odpovědět na naši otázku se tak zatím vlastně odkládá, protože ani nevíme, co to vůbec metafora je. Je tedy třeba blíže prozkoumat a ujasnit si samotný rozsah pojmu „metafora“. Věřím, že následkem rozdílné extenze pojmu metafory dochází i k přičítání rozdílné důležitosti tomuto jevu.

\footnotetext{
${ }^{36}$ Viz Gentner, Bowdle, Wolff \& Boronat (2001).
} 
V extenzi pojmu „metafora“ je značný zmatek následkem rozdílných definic, které jsou dány $\mathrm{v}$ teoriích mnohdy pouze implicitně. Jak již bylo naznačeno, tato neostrost pojmu se projevuje již u prvních dochovaných úvah o metafoře. Aristoteles chápe metaforu jako souhrnný název pro všechna obrazná vyjádření, ${ }^{37}$ zatímco Quintilianus a Cicero metaforu definují už pouze jako jeden z mnoha typů obrazného vyjádření a to takový, který vychází z podobnosti. ${ }^{38} \mathrm{~S}$ touto dichotomií se setkáváme i dnes. Někdy je metafora označena jako jeden $z$ tropů a je tak řazena na stejnou úroveň jako metonymie, ironie, hyperbola atd. Jindy je metafora chápána obecně jako jakýkoli obrazný výraz, tj. tropus. ${ }^{39}$

Uvedené teorie přistupují k problému toho, co je a co není metafora, většinou tak, že vyberou určité množství vzorových metafor. Tento výběr pak vlastně určuje rozsah pojmu metafora. Vhodně vybrané vzorové metafory jsou také později užity ke snadné verifikaci vytvořené teorie. Komparativistická pojetí chápou metaforu pouze jako zkrácené přirovnání. Davidson ve svém kauzálním pojetí zastává podobný př́stup metafora nás nutí ke srovnávání. ${ }^{40}$ Metafora má tak většinou formu typu „X je Y“ (,Achilles je lev“) a jakýkoli jiný typ obrazného vyjádření je pak v těchto pojetích spíše přehlížen. Ve starší verzi pojetí sémantického posunu je škála vzorových metafor už mnohem bohatší a teorie si poradí už i s metonymií, oxymoronem a katachrézí, protože tyto jsou detekovatelnými deviacemi uvnitř věty a lze jejich význam upravit do vhodné podoby metaforickým obratem. Moderní podoba pojetí sémantického posunu spolu s pragmatickým pojetím pak pomocí inferencí a principu spolupráce, dokážou vysvětlit i ironii, hyperbolu a obraznost obecně v širokém aristotelském chápání. Pojetí metafory jako kognitivního konceptu pak do pojmu metafora zahrnuje navíc i tzv. „mrtvé“ metafory (např. „Má ve společnosti vysoké postavení“). Extenze pojmu metafora je tak v tomto posledním pojetí nejširšsí.

Aby bylo vůbec možné zkoumání role metafory na poli významu, je třeba chápat pojem metafora nejširším možným způsobem a zahrnout tak pod tento pojem všechny výše uvedené teorie metafory. Pod pojem metafory tak musí spadat všechny tropy metonymie, ironie, hyperbola, synekdocha, katachréze atd. Pojem metafora je pak víceméně synonymem obraznosti. Dalším důvodem pro volbu tohoto širokého pojetí je i jistá tendence filosofie jazyka opomíjet a odsouvat do pozadí ostatní tropy, je-li metafora vymezena úzce. Jsem přesvědčen, že důvodem tohoto přehlížení dalších tropů je spíše snaha vyhnout se obtížím nežli snaha o detailnější a konkrétnější výzkum úzce vymezené metafory.

\footnotetext{
${ }^{37}$ Aristotelés (Poetika II, 21, 1457b).

${ }^{38}$ Hills (2012, kap. The Ancient Accounts).

${ }^{39}$ Pavelka (1982, s. 25).

${ }^{40}$ Lepore \& Stone (2010, s. 175).
} 
Navíc př́iklon k širokému vymezení je oprávněný i proto, že spíše než nějakým revolučním požadavkem je tento přístup charakteristickou tendencí projevující se ve vývoji zkoumání metafory. Znakem moderních verzí uvedených pojetí je totiž právě i rozšiřování extenze pojmu metafory.

Je-li ale metafora vymezována široce jako všechna obrazná vyjádření, spadá pod tento pojem poměrně velká část jazyka. Užívání širokého vymezení metafory tak už samo značně zpochybňuje druhotnost fenoménu metafory při zkoumání jazyka a významu.

\section{Problém podobnosti}

V klasickém, komparativistickém i kauzálním pojetí, je také patrný důraz na fenomén podobnosti. Role podobnosti $\mathrm{v}$ metafoře je předpoklad, který je mnohdy nekriticky přjímán z klasického antického pojetí. Co podobnost vlastně je a jak v metafoře funguje, není vždy jasné. Podobnost mezi věcmi je ale potenciálně nekonečná. To lze snadno ukázat na slavné hádance Lewise Carrolla „Jak je havran jako psací stůl?“ Budeme-li odpovídat nalézáním podobností mezi oběma jmenovanými, hrozí nám nekonečný výčet: „Na obou je brk.“, „Když do nich kopneš, je velká šance, že praskne nějaká kost.“, „Oba jsou a podílejí se tak na Bytí.“, „Názvy obou obsahují písmeno A.“, „Když je hodíš, letí.“, „Jsou to věci rozprostraněné (měřitelné, vážitelné atd.).“, „Jsou viditelní i bez mikroskopu.“, „Jsou nakreslitelní štětcem z velbloudí srsti.“, „Když je vcucne turbína letadla, hrozí nebezpečí havárie onoho letadla.“, „Jejich výskyt na povrchu Jupiteru je velmi nepravděpodobný.“ atd.

Podobnost je neudržitelná hlavně ale proto, že připisuje jsoucnům množinu jakýchsi rádoby objektivních kvalit, které ale ve skutečnosti nemohou být nezávislé na člověku. To je patrné už i z těch nejjednodušších a nejtypičtějších příkladů metafor, které mají zdůraznit vlastnosti jako statečnost („Achilles je lev“), krása (,Julie je slunce"), ošklivost, roztomilost atd. Určité osobě jsou přisuzovány vlastnosti, které za objektivní rozhodně nelze označit. Pokud jsou ale tyto vlastnosti neobjektivní (a na tom nemění nic ani fakt, že jejich připisování je mnohdy v rámci jisté kultury či skupiny součástí konsensu), pak už nelze mluvit o podobnosti, jejíž samotný pojem evokuje objektivnost a jistou verifikovatelnost, ale spíše o jakési kulturně a historicky podmíněné asociaci či podobné mentální operaci. Termínem asociace zde míním obecně jakékoli spojování mentálních obsahů, tedy nejen na základě vztahu podobnosti, ale i na základě dalších vztahů - např. časové či prostorové souvislosti, příčinnosti, kontrastu a pravděpodobně mnoha dalších. Tento vztah asociace je naznačen v článku M. Blacka, který pro něj užívá termín systém běžných asociací (system of associated 
commonplaces), ${ }^{41}$ článku M. Beardsleyho, který mluví o konotacích, ${ }^{42}$ a v teorii metafory J. Searla, který mimo termínu predpokladio v pozadí přímo používá termín asociace. $^{43}$

Vztah mezi věcmi, který v metafoře při zběžném a povrchním pohledu nazýváme podobnost, je ve skutečnosti mnohem komplikovanějším systémem souvislostí a odkazů. Nahradíme-li v popisu mechanismu metafory princip podobnosti préedstavou takovéhoto systému, který můžeme zatím nazývat jednoduše systém asociací, lze se pak mnohem snáze vyrovnat i s problematickými metaforami jako je např́klad „Richard je gorila“. ${ }^{44}$ Tato metafora naznačuje, že Richard je hrubián, hlupák a barbar a to i přes to, že gorily vynikají mezi zvíraty právě svojí jemností, plachostí a inteligencí. Protože tedy gorily hrubiánské rysy nemají, metafora na principu podobnosti založena být nemůže. Vysvětlení pomocí asociací je naopak v tomto případě úspěšné a lze jím snadno vysvětlit i další typy obrazných vyjádření. Vědění o gorilách je zatíženo historickým předsudkem o jejich hlouposti, který nám vytane na mysli mezi prvními, slyšíme-li slovo gorila. Nezáleží přitom na tom, kolik toho víme o gorilách. Kulturně a historicky podmíněný předsudek o gorilách je $\mathrm{v}$ nás zakořeněn natolik, že metaforu pochopíme velmi snadno.

Omezení role podobnosti nejen odstraňuje mnoho rozporů v teoriích metafory, ale také shrnuje pod jednu teorii většinu typů obrazných vyjádření. Odmítnutí podobnosti je tedy zároveň $\mathrm{v}$ souladu $\mathrm{s}$ požadavkem širokého vymezování pojmu metafory. Rozporuplnost a absurdita ironie, hyperboly, eufemismu a oxymóronu vyvolává myšlenkovou operaci nalezení významu na základě kontrastu, tj. dalšího z klasických asociačních vztahů známých např. z díla D. Huma. ${ }^{45}$ Katachréze je vytvářena jak na základě podobnosti, tak na základě časové či prostorové souvislosti, podobné rytmiky atd. Metonymie je dokonce definovaná jako přenášení významu na základě asociace, tedy jakési obecné neurčité souvislosti. ${ }^{46}$

Nahrazení podobnosti nadřazeným mechanismem asociací by však s sebou neslo ještě jeden snad dokonce zajímavější důsledek. Nahrazení objektivní podobnosti mentálními asociacemi totiž vyvolává otázku: „Jak se liší mentální reakce na slovo gorila ve větách: „Richard je gorila“ a „Támhle je gorila!“““ Není možné, že řetězová reakce asociací, které se spustí užitím slova „gorila“v tom, co zveme metaforou, je

\footnotetext{
${ }^{41}$ Black (1954, s. 287).

${ }^{42}$ Beardsley (1962, s. 294).

${ }^{43}$ Searle (1979a, s. 97).

${ }^{44}$ Př́íklady ze Searle (1979a, s. 89).

${ }^{45}$ Mandelbaum (2016).

${ }^{46}$ Merriam Webster - Dictionary.
} 
nakonec principiálně stejná jako reakce na slovo „gorila“"v doslovném vyjádření a jejich odlišnost leží pouze v množství asociací, které je nutné provést, aby bylo dosaženo naplnění konverzačních maxim či relevance? A nemůže nakonec právě tato řetězová reakce, detonovaná rozbuškou ve formě akustického či grafického aspektu slova, být tím co nazýváme význam? Odstraněním podobnosti v klasickém a komparativistickém pojetí metafory se tak dostáváme blízko k pragmatickému a konceptuálnímu pojetí, ve kterém ostrá linie mezi doslovným a obrazným mizí. Jazykový pragmatismus vidí význam slova ve způsobu užití tohoto slova, což lze snadno chápat jako asociaci na základě vztahu časové a prostorové souvislosti mezi slovem a tím, co znamená (např. vzpomínka na situaci, kdy bylo slovo užito v určitém významu). To pak ale může naznačovat, že princip chápání významu metafory může být stejný jako princip chápání významu jakéhokoli jiného doslovného vyjádření. To však potom vyvolává potřebu blíže prozkoumat další problematický prvek tradičních definic metafory - předjímání duality mechanismů významu.

\section{Předpoklad duality}

Další opakující se prvek jak v pojetí klasickém, kauzálním, v raných pragmatických pojetích, tak i $\mathrm{v}$ pojetí metafory jako sémantického posunu je totiž právě důrazné odlišování toho, co metaforická propozice říká doslovně, a toho, co se touto propozicí míní (resp. jak působí). „Metafora jednu věc říká, ale něco jiného znamená“ je zjednodušeným shrnutím přístupu těchto pojetí metafory. Dochází tím k naznačování potřeby rozlišení mezi behavioristicky chápaným říkáním a psychologicky chápaným míněním či působením. Jsem přesvědčen, že tato opozice je neopodstatněná. Jedná se o nekriticky prrijímaný předpoklad klasického starověkého chápání metafory. Přesto mnohé uvedené moderní definice metafory tímto předpokladem vysvětlují rozdíl mezi metaforou a doslovným vyjádřením. Teorie postavené na tomto residuu aristotelského chápání metafory pak pokračují v prohlubování odlišení metaforického a doslovného významu/působení, čímž vedou k představě rozštěpeného mechanismu významu. Následkem tohoto rozštěpení je pak nesouměřitelnost těchto pojetí s jinými, která tuto ostrou opozici odmítla či zpochybnila, např. právě pragmatické a konceptuální pojetí. Tento předpoklad nakonec pak vlastně štěpí i celý jazyk na část doslovnou a na část obraznou.

Argument pro toto odlišení, spočívající v připomenutí lidské schopnosti detekovat a odlišit metaforu $\mathrm{v}$ rámci promluvy, není plně dostačujícím pro přísné odlišování doslovného a metaforického významu a už vůbec ne pro předpoklad odlišného mechanismu stojícího za těmito významy. Detekce metafory může být alternativně vysvětlena i jako detekce odlišného stupně průzračnosti či komplikovanosti propozice, jak bylo například naznačeno v teorii relevance Sperbera a Wilsonové. V souvislosti s výše uvedenou představou mentálních asociací či pragmatických inferencí může být 
případ obrazného vyjádření například pouze označením vyjádření s nadstandardně dlouhým asociačním (resp. inferenčním) řetězem.

Věřím, že důvod důrazu na odlišování mechanismů obrazných a doslovných vyjádření spočívá spíše $\mathrm{v}$ postavení metafory $\mathrm{v}$ hierarchii fenoménů zkoumaných filosofií jazyka. Většina uvedených teorií metafory je budována až sekundárně z teorie doslovného významu. Jinak řečeno, provází je předpoklad, že mechanismus doslovného významu je již poznaný, vyřešený. ${ }^{47}$ Vysvětlit metaforu je pak až druhým krokem zkoumání a vytvořená teorie je pak mnohdy násilně naroubovaná na předcházející teorii doslovného významu. Protože metaforu většinou nejde vysvětlit způsobem, jakým byla přednostně vysvětlena doslovná vyjádření, zkonstruuje se ad hoc dodatečný vedlejší mechanismus pro vyjádření obrazná - přenos, změna atd., popř́ípadě se metafora odmítne a z jazyka vyloučí úplně. Důvodem, proč není spíše modifikována původní teorie významu a namísto toho je dodatečně doplněna výjimka z pravidla, je představa o malé důležitosti obrazných vyjádření $\mathrm{v}$ celku jazyka, popř́ípadě představa o jejich druhotnosti a podřízenosti doslovným vyjádřením. Tímto neduhem například, dle mého názoru, jednoznačně trpí kauzální pojetí metafory, které za účelem zachování pravdivostních podmínek a metafyzického realismu raději vykáže metafory mimo jazyk a upře jim význam.

$\mathrm{Z}$ výše uvedeného je nicméně důležité zdůraznit hlavně onen předpoklad obeznámenosti s tím, co je význam. Tento prvek je v problematických teoriích metafory velmi častý, ačkoli otázka významu samého je pravděpodobně nejvíce diskutovaným bodem filosofie jazyka vůbec. Předpoklad dvou odlišných mechanismů významu stojí na přesvědčení, že každé slovo má nějaký svůj opravdový význam, který je v metafoře přetransformován do významu odlišného, vedlejšího (resp. nejazykového psychologického účinku). Toto přesvědčení evokuje obraz pevného pravdivého a jistého poznání významu, které je nám $\mathrm{k}$ dispozici a na základě kterého lze pokračovat dále $\mathrm{v}$ poznávání i dalších méně důležitých prvků jazyka, zatím ne tak jasných a jistých, např. metafor. Když si však uvědomíme, že jediné pevné a jisté, co držíme v rukou, je nakonec pouze výkladový slovník obsahující lexikální významy slov, tj. význam slov v nulovém kontextu, lze vyjádřit oprávněnou pochybnost o stavu řešení otázky významu, protože identifikovat význam s na kontextu nezávislou poučkou ve slovníku je velmi diskutabilní. ${ }^{48}$ Zpochybnění otázky role „lexikálního“ významu v jazyce podal např́klad W. V. O. Quine v díle Word and Object $(1960)^{49}$ či již John Searle ve zmiňované teorii doslovného významu.

\footnotetext{
${ }^{47}$ Searle (1979a, s. 78).

${ }^{48}$ Pavelka (1982, s. 45).

${ }^{49}$ Marvan (2010, s. 149-150).
} 
Hlavním dodatečným podpůrným argumentem pro předpokládanou a předem přijatou podvojnost mechanismů významu u obrazného a doslovného vyjádření je také parafráze. Je-li možné metaforu parafrázovat, tzn. jde-li obrazné vyjádření redukovat na doslovné, pak to znamená, že existuje jistý jeden převoditelný význam přenášený mezi dvěma typy vyjádření. Tím by byla podvojnost mechanismů významu obhájena. Doslovnost by byla daná a obraznost by mohla vznikat přenosem doslovného významu na zástupný výraz. Nicméně zda je takováto parafráze-převod možná, je velmi pochybné. Podle M. Blacka se parafrází ztrácí velká část kognitivního obsahu metafory. ${ }^{50}$ D. Davidson, ač za jiným účelem než M. Black, také zpochybňuje parafrázi jako převod z obrazného do doslovného vyjádření. Metafora není podle něj převoditelná na doslovné vyjádření, stejně jako obraz není př̀voditelný na slova. ${ }^{51}$ Podle Searla nelze parafrázovat mnohdy ani velmi jasné a nekomplikované metafory. V prrípadě, že metaforu parafrázovat lze, pak je to možné jen přibližně a parafráze nikdy nebude plně adekvátní a část významu se vždy ztratí. ${ }^{52}$ Pokud však metafora není plně převoditelná a parafráze je spíše pouhým jiným vyjádřením ke stejnému tématu/objektu, pak už ani parafráze není dostatečným argumentem pro sekundárnost obrazného vyjádření (a tedy i argumentem pro odlišnost obrazného a doslovného významu).

Proti předpokladu duality pracuje i fakt, že v žádné definici metafory se nelze vyhnout chybě zvané definice kruhem - circulus vitiosus. Jak upozornil J. Derrida ve svém článku White Mythology (1982), ${ }^{53}$ při pozorném zkoumání konceptu metafory totiž vyjde najevo, že metafora sama je definována či vysvětlována pomocí metafor. Termíny jako objekt, figura, věc jsou samy $\mathrm{v}$ definici použity metaforicky. Př̀ definování pojmu metafory jsou tedy použity metafory, což je první případ definice kruhem. Metaforické jsou i termíny jako koncept, zakládat se na..., teorie apod. ${ }^{54}$ Dokonce slovo definice (z lat. de+finis tj. vymezit konec nebo hranici) je mrtvá metafora. Takže i na meta-úrovni při referování $\mathrm{k}$ definici metafory se setkáváme $\mathrm{s}$ metaforou. Třetím př́ípadem bludného kruhu je skutečnost, že nakonec i samotné slovo metafora je metafora. Řecké slovo $\mu \varepsilon \tau \alpha \varphi$ oṕ je složeninou předpony $\mu \varepsilon \tau \alpha$ tj. za/přes a slovesa $\varphi \varepsilon ́ p \omega$ tj. nosím a znamená tak v překladu do češtiny zhruba něco jako přenos. Výraz pro lidskou činnost nošení fyzických objektů a předpona odkazující k fyzickému prostoru či k času jsou obrazně užity k označení obrazného popisu. Takže vlastně nejen k popsání principu metafory, jakémukoli vyjádření se o tomto principu metafory, ale i k samotnému pojmenování tohoto principu je použit sám tento princip - metafora. Jasně

\footnotetext{
${ }^{50}$ Black (1954, s. 293).

${ }^{51}$ Davidson (1978, s. 47).

${ }^{52}$ Searle (1979a, s. 82-83).

${ }^{53}$ Viz Derrida (1982).

${ }^{54}$ Derrida (1982, s. 230).
} 
se zde ukazuje, že hledání ostré hranice mezi doslovností a obrazností je velmi problematické a možná i principiálně nemožné.

To, že metafora používá stejný mechanismus významu jako výrazy doslovné, je také patrné na zvláštním rysu metafory, kterým je jakási její důraznost či rétorická síla. Tuto rétorickou sílu nazývám intenzita. ${ }^{55}$ Intenzita, která je naprosto typickým rysem metafor, je právě nejpatrnějším projevem toho, že mechanismus významu metafor se nijak neliší od mechanismu významu doslovných vyjádření. K představení této intenzity je nejužitečnější následující př́kklad. ${ }^{56}$ Intenzita je nejpatrnější na rozdílu mezi metaforou a přirovnáním u pejorativních vyjádření. Metafora „Ty jsi kráva.“ má očividně jinou intenzitu než přirovnání „Ty jsi jako kráva.“ V prvním případě jde o tvrzení identity osočené osoby s hospodářským zvířetem. Osoba je nařčena ze sdílení všech vlastností a rysů krávy a ztráty rysů lidské bytosti. V druhém případě je naznačena jen jakási podobnost $\mathrm{v}$ jednom a jen výjimečně ve více rysech. Nikdy však ve všech. ${ }^{57}$ To, že v přirovnání není nikdy naznačeno sdílení všech rysů, tedy identity, je patrné také z dalšího př́kladu: „Jsi jako chytrý člověk“. Tímto přirovnáním je řečeno, že oslovená osoba není chytrý člověk, pouze s ním sdílí několik rysů, podobá se mu. Přirovnání je znovu mnohem slabší a je velmi vzdálené propozici vyjadřující totální identitu, tj. ,Jsi chytrý člověk“. Člověk popsaný jako pouze podobný chytrému člověku, na rozdíl od člověka, jemuž byla připsána identita s chytrým člověkem, má pak opodstatněné právo se urazit. Metafora tak svoji intenzitu získává právě tím, že je míněna doslovně, tedy úplně stejným způsobem jako přirovnání. Mluvčí nenaznačuje pouhou podobnost (tj. uvedená pejorativní věta nejde parafrázovat jako „Podobáš se hospodářskému zvířeti“) a zajisté tak nepoužívá žádný metaforický, nový, zvláštní a neobvyklý význam slova. Intenzita tak mimo rozlišení mezi doslovným přirovnáním a

${ }^{55}$ Tato intenzita, důraznost a rétorická síla metafory je také např́ḱlad hlavní slabinou jakékoli komparativistické teorie. Všechny tyto teorie totiž stojí na myšlence eliptičnosti metaforické věty, tj. na zamlčení jistých částí věty, které ale mají být podle těchto teorií stále míněné implicitně. Zamlčená má být povětšinou spojka „,jako“. Metafora „Julie je Slunce“ má mít identický význam jako přirovnání „Julie je jako Slunce“. Rozdíl v síle, důrazu či napětí, kterými disponuje první ne však druhá věta, je komparativisty většinou přehlížen.

${ }^{56}$ Tento př́íklad nicméně není v odborném textu běžný a může být považován za nevhodný. Proto se zde pro jistotu předem omlouvám doufaje, že účel ospravedlní prostředky.

${ }^{57} \mathrm{Na}$ první pohled se může zdát, že zde popírám vše, co bylo v předchozím textu řečeno o podobnosti. Bylo přece řečeno, že podobnost je nekonečná, tak jak je ted' možné, aby se přirovnání týkalo pouze několika málo rysů? Dovoluji si tuto nesrovnalost tvrdit proto, že jsem přesvědčen, že základní podobou přirovnání není forma $\underline{X}$ je jako $Y$ ale forma $\underline{X \text { je } v \text { rysu } Z}$ jako Y. Např́klad: „Ty(x) jsi krásná(z) jako princezna(y)“. A je-li rys $Z$, který je sdílený jak $X$ tak Y, zamlčen, je tomu tak nejspíše proto, že vyplývá z kontextu. Metafora není přirovnáním právě pro absenci rysu Z, z čehož vyplývá ona její intenzita. 
metaforou popírá i pojetí sémantického posunu i pojetí komparativistické. ${ }^{58}$ Urážka, která je očividně metaforou, by totiž ztratila obrovskou část své intenzity, kdyby byla chápána jako obrazné vyjádření založené na dílčích podobnostech. Toto zjištění pak samozřejmě můžeme aplikovat i na další slavné a mnohem korektnější prř́klady metafor. Plná síla pochvaly či uznání „Achilles je lev“ vychází z faktu, že je míněna i chápána doslovně. Metafora „Julie je Slunce“ říká přesně a jen a pouze to, že Julie je Slunce. Namísto dlouhého potenciálně nekonečného výčtu oceněníhodných vlastností (Julie je krásná, jedinečná, důležitá v Romeově životě atd.) vyjadřuje Romeo svůj postoj krátkým, úderným a úplným vyjádřením. Vyjádření je úplné, protože nepřipisuje Julii pouze nějaký omezený počet vlastností Slunce, jako to dělá přirovnání, ale Julii se Sluncem ztotožňuje. To potom ale znamená, že metafora a doslovné vyjádření pracují na stejném mechanismu, at' už je jakýkoli.

\section{Postavení metafory v teorii významu}

Analýza uvedených prvků teorií metafory mě tak vede $\mathrm{k}$ přesvědčení, že odlišnost mechanismu významu obrazných a doslovných vyjádření je neopodstatněný předpoklad vycházející ze samotného termínu „metafora“ a původních antických vysvětlení metafory. Tento předpoklad pak kontaminuje mnohé současné teorie metafory. Odmítnutí této neopodstatněné duality je potvrzováno také nevyhnutelným odmítnutím mechanismu podobnosti, odmítnutím parafrázovatelnosti metafory, odmítnutím „lexikálního“ významu a intenzitou metafory. Namísto násilného a možná principiálně nemožného hledání demarkační linie mezi doslovným a obrazným vyjádřením, je vhodnější odmítnout tuto opozici jako neopodstatněnou a toto odmítnutí využít při zkoumání významu. Tím se dostáváme k hlavní myšlence tohoto článku. Jaký je tedy potenciál metafory při zkoumání významu?

Tato otázka nás v tuto chvíli překvapivě nezavazuje potřebou zodpovězení otázky „Co je to vůbec metafora?““. V uvedeném zkoumání, rozšiřrování a dekonstrukci pojmu „metafora“ jsme se k zodpovězení této otázky nikterak nepřiblížili. Spíše naopak. Vysvětlení toho, co je metafora, ale ani nebyl úkol tohoto článku.

V současné chvíli lze tedy o metafoře říci maximálně to, že se jedná o něco $\mathrm{s}$ množstvím funkcís9 a zvláštních rysů, u čeho se na základě zpochybnění aspektů některých pojetí metafory (klasického, komparativistického, kauzálního a pojetí sémantického posunu) a $\mathrm{v}$ souladu s jinými pojetími metafory (pragmatického,

\footnotetext{
${ }^{58}$ Paradoxně intenzita na jednu stranu podporuje stejné závěry komparativistického pojetí, které přisuzuje metafoře doslovný význam namísto nějakého tajeného metaforického významu, na druhou stranu však stejné pojetí vyvrací svou pozicí kritéria k rozlišení metafory a přirovnání.

${ }^{59}$ Viz Pavelka (1982).
} 
konceptuálního) lze domnívat, že funguje na stejném mechanismu jako vyjádření doslovné.

Toto široké a volné pojetí metafory nám ale překvapivě vystačí, protože i v této podobě nám dovoluje uvažovat o postavení metafory na poli významu. V odmítnutí předpokladu duality se totiž ukazuje, že role metafory na poli významu je naprosto zásadní a to proto, že mechanismus konstituování významu metafory se neliší od mechanismu konstituování významu doslovného vyjádření, popř. se liší pouze ve stupni. Tím se nám ukazuje zajímavá možnost, jíž je využití potenciálu metafory zastávat na poli zkoumání významu roli kritéria hodnocení. Věřím, že výše uvedené úvahy podporují tuto hypotézu a že by metafora opravdu mohla sloužit teorii významu jako měřítko její úspěšnosti. Nejsou-li totiž obrazná vyjádření odlišným typem vyjádření než vyjádření doslovná, ale pouze odlišným stupněm vyjádření pracujících na stejném mechanismu významu, jsou pak stupněm složitějším. Tato jistá nadřazenost nad jednoduššími doslovnými vyjádřeními pak dává obrazným vyjádřením opodstatněné právo být kritériem pro ověření platnosti teorie významu. O koncepci vysvětlující pouze jednoduché případy jevu lze totiž oprávněně pochybovat. Jsem tak přesvědčen, že díky těmto svým specifickým kvalitám může metafora sloužit jako nástroj k přezkoušení účinnosti teorie významu, $\mathrm{k}$ procesu hodnocení, $\mathrm{k}$ modifikaci či dokonce $\mathrm{k}$ budování nové teorie významu.

Tuto hypotézu podporuje i široké pojetí metafory a frekvence výskytu obrazných vyjádření v jazyce. G. Lakoff a $\mathrm{M}$. Johnson svou prací představili možnost chápat metafory a obrazná vyjádření obecně jako jev v jazyce spíše dokonce převažující. ${ }^{60}$ Mimo to se také ukazuje, že metafora hraje i velmi důležitou, pravděpodobně až klíčovou roli ve vývoji jazyka. ${ }^{61}$ Kvantita obrazných vyjádření v jazyce se totiž většinou vysvětluje pomocí procesu umírání metafor. Často používaná a všeobecně známá metafora se v průběhu času skupině uživatelů natolik vžije, že se na její metaforický původ zapomene. Lze se setkat i s označením tohoto procesu termínem konvencionalizace. ${ }^{62}$ Úspěšná metafora se opakovaným užitím tak intergeneračně proměňuje z obrazného vyjádření na doslovné a stává se pevným kodifikovaným prvkem slovní zásoby. Umíráním metafor není míněn jen například proces vzniku idiomů. I běžné fráze jako ,vysoké společenské postavenî, ,střední třída“, „sféra podnikání“ jsou př́klady takových vyjádření, která jsou původem metaforická. Jsem přesvědčen, že důsledný etymologický rozbor slovní zásoby daného jazyka by objevil, že takovýchto mrtvých metafor je jazyk plný a že nelze dokonce jednoznačně vyloučit ani onu extrémní možnost, že slovní zásoba je vlastně množinou mrtvých metafor.

\footnotetext{
${ }^{60}$ Viz Lakoff \& Johnson (2002).

${ }^{61}$ Smith \& Höfler (2015, s. 133).

${ }^{62}$ Tamtéž, s. 126.
} 
Navíc ve vývoji jazyka metafora nerozšiřuje a nerozvíjí pouze slovní zásobu, ale ovlivňuje také samotnou gramatiku jazyka. Jako nejevidentnější příklad lze uvést gramatický konstrukt anglického jazyka „to be going to“, pomocí kterého se v angličtině tvoří jeden z jejích budoucích časů. Původní význam tohoto konstruktu se týkal samozřejmě místního pohybu, ale v průběhu času a nespočtu metaforických užití získal i význam intence a posléze se stal oficiálním způsobem tvoření futura. Tento případ není nikterak ojedinělý a podobné změny lze nalézt ve více jazycích. ${ }^{63}$ Jsou-li však obrazná vyjádření přímo generátorem vyjádření, která označujeme za doslovná, či lexikálních významů a mnohdy ovlivňují i gramatickou rovinu jazyka, potom je role metafory $\mathrm{v}$ teorii významu natolik dominantní, že by teorie významu mohla být na metafoře i založená. Protože teorie významu nemůže odhlížet od frekvence obrazných vyjádření $\mathrm{v}$ přirozeném jazyce ani od vývoje jazyka a procesu geneze významu, považuji tyto kvantitativní rysy metafory za další argument pro roli metafory jako kritéria hodnocení teorie významu.

\section{Závěr}

Cílem článku nebyla ani snaha o vysvětlení toho, co je metafora, ani snaha o vybrání nejlepší teorie metafory $\mathrm{z}$ představené nabídky formou kritiky jedněch teorií a vyzdvihováním druhých. Ač to tak nemusí vypadat, mou snahou bylo primárně zpochybnění zdrojů banalizujících tendencí objevujících se v teoriích metafory, protože následkem tohoto odmítnutí se ukazuje velmi zajímavý potenciál fenoménu metafory.

Za nejzávažnější zdroj představy o druhotnosti metafor při zkoumání významu považuji předpoklad odlišnosti sémantického mechanismu metafory od mechanismu významu doslovného. Tento předpoklad je postulován již od antiky a lze ho detekovat dodnes $\mathrm{v}$ mnohých současných teoriích metafory. $\mathrm{Z}$ rozboru tohoto předpokladu $\mathrm{i}$ dalších nejasností, které kolem metafory panují (problém podobnosti, intenzita metafory), pak vyplývá, že tento předpoklad a z něj následně vycházející oddělení zkoumání obrazných vyjádření od tradičního zkoumání významu doslovných vyjádření jsou s největší pravděpodobností neopodstatněné.

Odmítnutí odlišnosti mechanismů konstituování významu obrazných a doslovných vyjádření a jejich chápání jako pouhých různých stupňů stejného vrhá nové světlo na roli metafory na poli zkoumání významu. Metafora není pouze plnohodnotnou součástí tohoto zkoumání, ale zároveň se ukazuje i její zajímavý potenciál zastávat roli prubiřského kamene teorií významu. Onu problematičnost a množství komplikací, které provázejí každou teorii metafory a pro které je tak metafora někdy nazývána temnou

${ }^{63}$ Tamtéž, s. 135. 
stranou filosofie jazyka, ${ }^{64}$ lze chápat také jako výzvu, se kterou se teorie významu musí vyrovnat a prokázat tak stupeň své úspěšnosti. V silnější podobě tohoto návrhu pak metafora může být chápána nejen jako nástroj k hodnocení těchto teorií, ale také jako nástroj k jejich falsifikování, modifikování či př́imo k jejich vytváření.

Vyvrácení odlišnosti sémantických mechanismů metafory a doslovných vyjádření se může zdát dostačujícím argumentem pro podepření hypotézy o metafoře jako hodnotícím kritériu, nicméně to rozhodně není argument jediný. Odmítneme-li tradiční banalizaci metafory jako pouhé jazykové dekorace a tedy okrajového jevu, ukazuje se až překvapivá důležitost tohoto typu vyjádření i na jiných místech. Důležitost metafory vzrůstá, i pokud se zbavíme nevhodného úzkého vymezení pojmu a chápeme-li pojem metafory široce, tedy jako množinu všech obrazných vyjádření (metonymie, ironie, synekdocha, personifikace, katachréze atd.). Když totiž shrneme pod pojem metafory všechna obrazná vyjádření a mrtvé metafory, pak už nelze mluvit o jakékoli marginálnosti tohoto jevu a deviaci od normy. Široce chápaná metafora $\mathrm{v}$ jazyce totiž dost možná převažuje. V diachronním pohledu na jazyk se dále ukazuje, že metafora a její životní cyklus (tj. proces umírání metafor) hraje velmi významnou roli ve vývoji slovní zásoby a gramatiky jazyka. Je-li pak možné, že je metafora v jazyce převažujícím jevem a zároveň vlastně přímo generátorem doslovných vyjádření či lexikálních významů, a přihlédneme-li zároveň i k její intenzitě, konverzačnímu účinku, který vyvolává v posluchačích, je potom její role v teoriích významu nejen naprosto zásadní, ale zároveň ji lze znovu chápat i jako vhodné kritérium k hodnocení těchto teorií.

$\mathrm{Na}$ základě těchto úvah jsem přesvědčen, že otázka metafory by tak měla být zahrnuta do jádra teorie významu a nebýt řešena až následnou, vedlejší a dodatečnou modifikací vytvořenou ad hoc pro potvrzení této teorie významu. Teorie významu by se za prvé měla vyhnout častému nutkání k banalizaci obrazných vyjádření. Toto považuji za největší nedostatek, který objeví-li se v teorii významu, měl by být důvodem $\mathrm{k}$ její alespoň částečné falsifikaci, protože tato banalizace není nikterak opodstatněná. V případě, že se teorie významu vyhne této banalizaci obrazných vyjádření, musí se dále vyrovnat s otázkou duality obrazných a doslovných vyjádření, s otázkou kvality a kvantity metafor $\mathrm{v}$ jazyce (frekvence, intenzita, vývoj jazyka atd.). Způsob, opodstatněnost a plauzibilita toho, jak se teorie významu vyrovná s těmito otázkami, může být pak chápán jako ukazatel úspěšnosti této teorie. Vyhýbání se těmto otázkám bude naopak signalizací nedostatků této teorie.

\section{Literatura}

Aristotelés (1999): Rétorika; Poetika. Petr Rezek, Praha.

${ }^{64}$ Takto metaforu označil W. Lycan (2008). 
Beardsley, M. (1962): „The Metaphorical Twist.“ Philosophy and Phenomenological Research 22: 293-307.

Black, M. (1954): „Metaphor.“ Proceedings of the Aristotelian Society 55: 273-94.

Black, M. (1979): „More About Metaphor.“ In Metaphor and thought, ed. A. Ortony, Cambridge University Press, New York, 1993, s. 19-41.

Davidson, D. (1978): „What Metaphors Mean.“ Critical Inquiry 5(1): 31-47.

Derrida, J. (1982): „White Mythology: Metaphor in the Text of Philosophy. “In Margins of Philosophy, J. Derrida, University of Chicago Press, Chicago, 1982, s. 207271.

Fogelin, R. (1988): Figuratively Speaking. Yale University Press, New Haven.

Gentner, D., Bowdle, B. F., Wolff, P. \& Boronat, C. (2001): „Metaphor Is Like Analogy.“ In The Analogical Mind: Perspectives from Cognitive Science, D. Gentner, K. J. Holyoak \& B. N. Kokinov, MIT Press, Cambridge, Mass., 2001, s. 199-253.

Grice, H. P. (1975): „Logic and Conversation.“ In Studies in the Way of Words, H. P. Grice, HUP, Cambridge (Mass) - London, 1989, s. 22-40.

Hills, D. (2012): „Metaphor.“ In The Stanford Encyclopedia of Philosophy [on-line], ed. E. Zalta, [cit. 10. 2. 2016], Dostupné z: <http://plato.stanford.edu/archives/win2012/entries/metaphor/>.

Lakoff, G. \& Johnson, M. (2002): Metafory, kterými žijeme. Host, Brno.

Lakoff, G. (1993): „Contemporary Metaphor.“ In Metaphor and Thought, ed. A. Ortony, Cambridge University Press, New York, 1993, s. 202-251.

Lakoff, G. (2008): „The Neural Theory of Metaphor.“ In The Cambridge Handbook of Metaphor and Thought, ed. R. Gibbs, Cambridge University Press, New York, 2008, s. 17-38.

Lepore, E. \& Stone, M. (2010): „Against Metaphorical Meaning.“ Topoi 29: 165-180.

Lycan, G. (2008): Philosophy of Language: A Contemporary Introduction. Routledge, New York.

Mácha, J. (2012): „Searle on Metaphor.“ Organon F 19: 186-197.

Mandelbaum, E. (2016): „Associationist Theories of Thought.“ In The Stanford Encyclopedia of Philosophy [on-line], ed. E. Zalta, [cit. 20. 3. 2016], Dostupné z: $<$ http://plato.stanford.edu/archives/spr2016/entries/associationist-thought/>.

Marvan, T. (2010): Otázka významu: cesty analytické filosofie jazyka. Togga, Praha.

Merriam Webster - Dictionary [on-line], Heslo: „Metonymy“ [cit. 19. 3. 2016], Dostupné $\mathrm{z}:\langle\mathrm{http}: / / \mathrm{www} \cdot \mathrm{merriam}-\mathrm{webster} . \mathrm{com} /$ dictionary/metonymy>.

Pavelka, J. (1982): Anatomie metafory. Blok, Brno.

Peregrin, J. (2005): Kapitoly z analytické filosofie. Filosofia, Praha.

Richards, I. A. (1936): The Philosophy of Rhetoric. Oxford University Press, London, New York. 
Rorty, R. (1989): Contingency, Irony, and Solidarity. Cambridge University Press, New York.

Searle, J. (1979a): „Metaphor.“ In Expression and Meaning: Studies in the Theory of Speech Acts, J. Searle, Cambridge University Press, Cambridge, New York, 1979, s. $76-116$.

Searle, J. (1979b): „Literal Meaning.“ In Expression and Meaning: Studies in the Theory of Speech Acts, J. Searle, Cambridge University Press, Cambridge, New York, 1979, s. 117-136.

Smith, A. D. M. \& Höfler, S. H. (2015): „The Pivotal Role of Metaphor in the Evolution of Human Language." In Metaphor and Metonymy across Time and Cultures: Perspectives on the Sociohistorical Linguistics of Figurative Language, ed. J. E. Díaz Vera, De Gruyter Mouton, Boston, 2015, s. 123-140.

Sperber, D. \& Wilson, D. (2008): „A Deflationary Account of Metaphors.“ In The Cambridge Handbook of Metaphor and Thought, ed. R. Gibbs, Cambridge University Press, New York, 2008, s. 84-105. 